\title{
ROZWÓJ KATEDR I BADAŃ FILOLOGICZNYCH Z ZAKRESU FILOLOGII KLASYCZNEJ ORAZ GERMANISTYKI, ROMANISTYKI I ANGLISTYKI NA UNIWERSYTETACH KRAKOWSKIM I LWOWSKIM W LATACH 1850-1918
}

\author{
Maria Stinia \\ Uniwersytet Jagielloński w Krakowie
}

\begin{abstract}
THE DEVELOPMENT OF PHILOLOGICAL RESEARCH IN CLASSICAL PHILOLOGY AND GERMANIC, ROMANCE AND ENGLISH STUDIES AT THE UNIVERSITIES OF KRAKOW AND LVIV IN THE YEARS 1850-1918
\end{abstract}

The years 1850-1918 were a period of intense development for the Jagiellonian and Lviv Universities. This process was especially visible when it comes to philological studies. On their example we can see the impact of reforms which stimulated the emergence of depatments and evolution of interests in scholarly research - from classical languages to modern philologies. The universities took up a conscious and independent process of building departments in the field of Romance and English languages, which added to their prestige. In the field of classical philology, after the first generation of German universities graduates, native scholars appeared. The Germanic departments were still entrusted to scholars from the German language areas, whereas for the Romance and English studies, they were given over to the alumni of Galician universities. Apart from the field of classical philology, the universities did not build up any major research programs. The scholars pursued their own broad interests, and because they had a great general humanistic foundation and knowledge of a few to dozen foreign languages, they developed numerous detailed studies, comparative studies and syntheses, and disseminated current research in textbooks and dictionaries.

Key words: Jagiellonian University, University of Lviv, English philology, Romance philology, Germanic philology, Latin and Greek philology.

Słowa kluczowe: Uniwersytet Jagielloński, Uniwersytet im. Cesarza Franciszka I we Lwowie, anglistyka, romanistyka, germanistyka, filologia klasyczna. 
Obowiązujący od połowy XIX wieku model działania uniwersytetów austriackich, opierający się na stabilnym finansowaniu przez państwo i bez prymatu realizacji celów utylitarnych, pozwolił na bardzo intensywny rozwój badań naukowych. Wolność nauki i nauczania były w tym czasie podstawowym paradygmatem funkcjonowania uniwersytetów. Upowszechnienie się formuły uniwersytetu dydaktyczno-badawczego oraz wykształcenie się pojęcia międzynarodowej wspólnoty uczonych pozwoliły na szybką transmisję nauki i dalszą jej profesjonalizację. Instytucjonalne zapotrzebowanie na nową wiedzę stało się cechą charakterystyczną w środowisku uczonych i rzadko występowało poza ich społecznościami ${ }^{1}$. Rozwój badań oraz ich kulturotwórcza rola dla rozwoju państw i narodów nie były już przedmiotem polemik i dyskusji. Profesjonalizacja nauki oznaczała również zaakceptowanie faktu, że w przestrzeni społecznej istnieją odpowiednie instytucje badawcze pełniące uznaną powszechnie funkcję, a uczony wszedł w ich sformalizowane struktury, w których miał określone obowiązki. Bycie badaczem stało się także sposobem na zarobkowa$n i^{2}$, a towarzyszył temu wzrost autorytetu naukowca wyznaczający mu wyjątkową rolę społeczną.

Przeprowadzenie w połowie wieku wzorowanych na modelu pruskim, ogólnoaustriackich reform całego systemu edukacyjnego, sygnowane przez ministra Leo Thuna, a faktycznie opracowane przez filologa Hermana Bonitza i prawnika Franza Exnera, zmieniło sposób funkcjonowania wydziałów filozoficznych ${ }^{3}$. Przebudowa systemu edukacyjnego wprowadziła i spopularyzowała ośmioletnie gimnazjum klasyczne kończące się maturą umożliwiającą wolny wstęp na wszystkie kierunki studiów uniwersyteckich. Koncepcja zakładała, że dzięki podbudowie filologicznej oraz dostarczeniu niezbędniej wiedzy ogólnej z różnych dyscyplin szkoła odpowiednio przygotuje kandydatów do studiów wyższych na wszystkich wydziałach. Istotną rolę $\mathrm{w}$ nowym systemie wyznaczono odpowiednio przygotowanym filologom, zwłaszcza klasycznym. Starano się zatem wzmacniać obsadę odpowiednich katedr, co znacznie wpłynęło na rozwój uczelni oraz przyspieszyło proces kształtowania się nowych kadr naukowych. Usamodzielnienie się wydziałów filozoficznych oraz wprowadzenie systemu habilitacji jako niezbędnego warunku kariery naukowej przyspieszyły rozwój badań także na uniwersytetach galicyjskich w Krakowie i we Lwowie.

Na rozwój nauki na terenie Galicji miała ponadto wpływ sytuacja polityczna, która umożliwiła polonizację oświaty oraz usprawniła funkcjonowanie uniwersytetów. $\mathrm{Z}$ racji lokalizacji na peryferiach monarchii ich finansowanie było znacznie skromniejsze, ale istnienie dwóch placówek naukowych w jednym kraju koronnym stanowiło wyjście poza obowiązujący jeszcze w pierwszej połowie wieku zwyczaj działania jednego takiego ośrodka. Pojawienie się instytucji docentów prywatnych

1 S. Amsterdamski, Tendencje rozwoju nauki w II połowie XIX wieku [w:] Historia nauki polskiej, t. IV: 1863-1918, cz. III, red. tomu Z. Skubała-Tokarska, Warszawa 1987, s. 18.

2 Ibidem, s. 23.

3 M. Stinia, Jagiellonen-Universität in den Zeiten des Ministers Leo Thun (1849-1860) [w:] Die Thun-Hohenstein 'schen Universitätsreformen 1849-1860. Konzeption - Umsetzung - Nachwirkungen, Hrsg. B. Mazohl, Ch. Aichner, Wien 2017, s. 198-220. 
dało podstawy do budowy własnej kadry, a habilitacja stała się warunkiem uzyskania katedry ${ }^{4}$. Ogłoszenie reform nie oznaczało automatycznie wprowadzenia w życie systemu habilitacji. W wypadku uczelni galicyjskich proces ten został wyraźnie zahamowany $w$ erze Bacha $i$ wznowiony wraz z procesem liberalizacji sytuacji politycznej w monarchii. Co prawda, pierwsze na ziemiach polskich postępowanie habilitacyjne według nowych przepisów odbyło się na uniwersytecie we Lwowie w 1850 roku, kiedy to przeprowadzono habilitację prawnika Michała Koczyńskiego, ale przed 1869 rokiem były one zjawiskiem rzadkim ${ }^{5}$. Na Uniwersytecie Jagiellońskim do roku 1918 przeprowadzono ogółem 275 habilitacji, z czego na Wydziale Filozoficznym 123, a jedna piąta z nich (28) przypadła na nauki filologiczne; dwie habilitacje zostały przeniesione $-\mathrm{z}$ uniwersytetu $\mathrm{w}$ Wiedniu (Leona Mańkowskiego) oraz z uniwersytetu lwowskiego (Leona Strenbacha) ${ }^{6}$. Na uniwersytecie lwowskim przeprowadzono ogółem 205 habilitacji, z czego na Wydziale Filozoficznym - $92^{7}$.

Wiek XIX przyniósł rozwój badań filologicznych w dwóch kierunkach - historyczno-literackim oraz językoznawczym. Oba wynikały z panującej powszechnie doktryny historyzmu w badaniach naukowych. Spośród wielu czynników dominujące znaczenie dla rozwoju polskich badań filologicznych miały ogólnoświatowe tendencje oraz szybszy przepływ informacji między uczonymi, znacznie poszerzający horyzonty badawcze. Dostrzeżenie podobieństw między sanskrytem, greką i łaciną oraz koncepcja prajęzyka i językowej rodziny indoeuropejskiej autorstwa Williama Jonesa (1746-1794), a także działalność naukowa Franza Boppa (1794-1867) i stworzenie dla niego katedry sanskrytu (w 1816 r. napisał on pracę O systemie koniugacyjnym sanskrytu w porównaniu z systemem greckim, łacińskim, perskim i germańskim) nakierowały autorów dziewiętnastowiecznych prac badawczych na studia nad typologią języków i językoznawstwo porównawcze (szkoły staro- i młodogramatyczne). W zakresie badań historyczno-literackich charakterystyczne były tworzenie wielkich syntez oraz - co ważne - studia nad własnym językiem i dorobkiem literackim. W sytuacji, w jakiej funkcjonowało społeczeństwo polskie, stanowiło to czynnik niezmiernie istotny, pobudzający do działania i wprost wpływający na tworzenie pierwszych szerokich programów badawczych. Przykładem może być zjazd ku czci Jana Kochanowskiego z 1884 roku$^{8}$. Wydzielenie kierunków historyczno-literackiego oraz językoznawczego stanowiło charakterystyczny element w rozwoju katedr filologicznych na ziemiach zaboru austriackiego. Doszło do tego również praktyczne kształcenie językowe na uniwersytetach w postaci lektoratów, które także stanowiło bodziec do

4 Niekiedy zwalniano $\mathrm{z}$ tego warunku wyjątkowo wybitnych, legitymujących się znakomitymi osiągnięciami badaczy.

5 K. Michalewska, Habilitacje w Uniwersytecie Jagiellońskim 1848-1918, Kraków 1963, s. 84.

6 Ibidem, s. 91, 110-123.

7 J. Dybiec, Uniwersytet Lwowski pod zaborem austriackim [w:] Universitati Leopoliensi. Trecentesimum quinquagesimum anniversarium suae fundationis celebranti in memoriam, red. W. Lehman, Kraków 2011, s. 73; M. Stinia, Uniwersytet Lwowski [w:] Szkolnictwo i oświata w Galicji 1772-1918, red. J. Dybiec, J. Krawczyk, A. Meissner, K. Szmyd, Galicja i Jej Dziedzictwo, t. 22, Rzeszów 2015, s. 206-222.

8 Pamiętnik zjazdu historyczno-literackiego imienia Jana Kochanowskiego. Archiwum do dziejów literatury i oświaty w Polsce, t. V, Kraków 1886. 
głębszych dociekań i niekiedy dawało początek dalszym badaniom naukowym. Na Uniwersytecie Jagiellońskim w połowie XIX wieku, już po reformach Thuna, funkcjonowały cztery katedry filologiczne: dwie katedry literatury klasycznej, katedra literatury polskiej oraz języka i literatury niemieckiej ${ }^{9}$.

\section{FILOLOGIE KLASYCZNE}

Dokonane zmiany w edukacji na poziomie szkoły średniej, w której podstawą nauczania i wychowania były łacina i greka (obecne w gimnazjum odpowiednio przez osiem i sześć lat), spowodowały, że na galicyjskich uniwersytetach nastąpił (inspirowany przez państwo) szybki rozwój filologii klasycznej. Tradycja jej funkcjonowania na UJ sięgała średniowiecza i miała za sobą okres intensywnego rozwoju w latach 60. i 70. XVI wieku. Późniejsze lata były już mniej pomyślne ${ }^{10}$. Od połowy XIX wieku rozwój kierunków filologicznych zapoczątkowany został właśnie w dziedzinie filologii klasycznej. Już w 1850 roku Thun wystosował pismo do Senatu UJ z uwagą o konieczności wzmocnienia katedry filologii klasycznej o profesurę nadzwyczajną. Kandydata wskazał Bonitz w osobie Antoniego Małeckiego, nauczyciela gimnazjalnego słynnego poznańskiego Gimnazjum św. Marii Magdaleny. Małeckiego z Bonitzem łączyło to, że obaj w czasie studiów berlińskich byli uczniami znakomitych filologów - Augusta Böckha i Karla Lachmanna ${ }^{11}$. Pomimo wysunięcia przez senat kandydatury Adolfa Mułkowskiego ${ }^{12}$ to właśnie Małecki przez sześć półroczy - od semestru letniego 1850 roku do zimowego w roku akademickim 1852/1853 - działał na UJ. Miał on obowiązek nauczać pięć godzin w tygodniu, kładąc nacisk na odpowiednie wykształcenie przyszłych filologów - nauczycieli gimnazjalnych. Szczególnie starannie przygotowanym pierwszym wykładem zdobył sobie uznanie słuchaczy. Zwrócił w nim uwagę na znaczenie nauk filologicznych jako postawy wychowania $\mathrm{w}$ szkole i podjął polemikę z ówczesnymi poglądami o ich zbędności i nieprzydatności ${ }^{13}$. Ogłosił drukiem Prelekcje o filologii klasycznej i jej encykopedji miane w pótroczu letnim 1850 roku (Kraków 1851). W listopadzie 1850 roku Małeckiego zwolniono z wykładów (przy zachowaniu profesury), powierzając mu

9 Katedra oznaczała etat profesorski z danego zakresu.

10 J.S. Gruchała, Philologia Perennis. Tradycje badań filologicznych w Akademii Krakowskiej do początków XIX wieku [w:] Ztota Księga Wydziatu Filologicznego, red. J. Michalik, W. Walecki, Kraków 2000, s. 30-31.

11 B. Gubrynowicz, Antoni Matecki (1821-1913), Lwów 1920, s. 16; W. Ogrodziński, Wielkopolanie na katedrze filologii klasycznej w Krakowie w XIX wieku, Poznań 1936, s. 2.

12 Adolf Mułkowski (1812-1867), filolog klasyczny, nauczyciel w Liceum św. Anny, bibliotekarz Biblioteki Jagiellońskiej, edytor źródeł (R. Dutkowa, Adolf Mułkowski (1812-1867) [w:] Polski Stownik Biograficzny [dalej: PSB], t. 22, 1977, s. 260).

13 Michał Wiszniewski we wstępie do swojej historii literatury polskiej podkreślał brak związków pomiędzy literaturą klasyczną a współczesną (M. Wiszniew ski, Historia literatury polskiej, t. 1, Kraków 1840, s. 42). 
funkcję dyrektora Gimnazjum św. Anny w Krakowie. Kiedy jednak przeprowadzono germanizację tej szkoły, złożył rezygnację. Zajął się badaniami nad literaturą grecką i rzymską oraz elementami publicznego prawa rzymskiego ${ }^{14}$. Najważniejszym rezultatem pobytu Małeckiego w Krakowie było założenie w 1851 roku seminarium filologicznego wraz z systemem nagród i stypendiów za pisanie prac seminaryjnych dla uczestników - kandydatów na nauczycieli. Jego autorskim dziełem był statut seminarium. Biblioteka seminaryjna mieściła się początkowo w mieszkaniu Małeckiego, następnie w Bibliotece Jagiellońskiej, by ostatecznie znaleźć pomieszczenie w nowo wybudowanym Collegium Novum (1887). Jako uczeń Leopolda Rankego był doskonale przygotowany do stosowania metod historycznych w badaniach, co też wykorzystywał na ćwiczeniach seminaryjnych. Małecki na fali germanizacyjnej i na podstawie anonimowych denuncjacji oskarżających go o brak lojalności wobec państwa austriackiego na mocy postanowienia z 3 grudnia 1852 roku został pozbawiony wykładów i wydalony z uczelni wraz z Antonim Helclem, Wincentym Polem i Józefatem Zielonackim ${ }^{15}$. Po kilku miesiącach uzyskał jednak nominację na stanowisko profesora zwyczajnego na uniwersytecie w Innsbrucku. Tam podjął decyzję o zmianie zainteresowań badawczych - zrezygnował z badań nad filologią klasyczną na rzecz literatury polskiej i w 1856 roku objął katedrę literatury polskiej we Lwowie ${ }^{16}$. Jego następcami w Krakowie zostali wykładający po niemiecku Bernard Jülg ${ }^{17}$ oraz Gustaw Linker. Przez kolejną dekadę kierowali oni filologią klasyczną na UJ. Dopiero wraz z postępującą polonizacją dokonano zmian na katedrach filologicznych - ten pierwszy w 1861 roku odszedł do wciąż zgermanizowanego uniwersytetu we Lwowie, a dwa lata później odszedł także Jülg. Wakująca po Linkerze katedra miała mieć już polski język wykładowy. Proces wyboru nowego kandydata trwał długo i postanowiono wspomóc się procedurą konkursową. W 1863 roku nastąpiła konieczność obsady już dwóch katedr. Wykłady w języku niemieckim powierzano w zastępstwie historykowi Antoniemu Wachholzowi. W marcu 1864 roku swoją kandydaturę na katedrę filologii klasycznej z polskim językiem wykładowym zgłosił doktor Alfred Brandowski pochodzący (podobnie jak Małecki) z Wielkopolski. Powołano go na katedrę we wrześniu tego roku, ale ze względu na wcześniejsze zobowiązania nie mógł jej objąć wcześniej niż pod koniec marca 1865 roku. Brandowski studiował na uniwersytecie wrocławskim oraz berlińskim, uczestniczył w seminariach filologicznych i historycznych, między innymi Fryderyka Haasego i Augusta Rossbacha we Wrocławiu oraz Augusta Boeckha i Maurycego Haupta w Berlinie, gdzie również uczestniczył w ćwiczeniach historycznych Rankego ${ }^{18}$. Po uzyskaniu stopnia doktora i zdaniu egzaminów nauczycielskich uczył w gimnazjum w Wałczu, a następnie

${ }_{14}$ Skład Uniwersytetu Jagiellońskiego w Krakowie oraz wykaz przedmiotów naukowych wyktadać się majacych w pótroczu letnim roku szkolnego 1851/1852, Kraków 1852, s. 13.

15 B. Gubrynowicz, op. cit., s. 16; W. Ogrodziński, op. cit., s. 86.

16 B. Gubrynowicz, op. cit., s. 89, 94.

17 B. Jülg przebywał w Krakowie do 1863 r., a następnie wykładał w Innsbrucku.

18 W. Madyda, Z dziejów filologii klasycznej w Uniwersytecie Jagiellońskim [w:] Wydział Filologiczny Uniwersytetu Jagiellońskiego. Historia katedr, red. W. Taszycki, A. Zaręba, Kraków 1964, s. $48-49$. 
w szkole realnej w Poznaniu. Intensywniejszą pracę naukową na UJ rozpoczął po roku 1868. Jego zainteresowania, podobnie jak wielu ludzi z jego pokolenia, były szerokie, od łacińskich tekstów polskich po poezje Owidiusza, Wergiliusza czy Horacego. Zajmował się też biografistyką oraz edycjami źródłowymi. Dla studentów był przyjacielski i opiekuńczy, choć przy egzaminach surowy ${ }^{19}$. Wykładając, skupiał się na gramatyce łacińskiej i historii literatury klasycznej. Na seminariach pracował na przemian nad literaturą grecką i rzymską. Ze względu na zły stan zdrowia nie kierował nimi od semestru letniego 1876/1877. Do jego wychowanków należeli między innymi: Franciszek Habura, Józef Winkowski, Leon Kulczycki, Stanisław Bednarski, Józef Taborski, Roman Zawiliński, Jan Czubek, Bolesław Kruczkiewicz. Do roku akademickiego 1867/1868 Brandowski był jedynym profesorem filologii klasycznej. Wówczas to drugą katedrę, na której wykład nadal miał się odbywać po niemiecku, objął Jan Wróbel (Wrobel) pochodzący z Opola, a habilitowany w Petersburgu. W związku z pełną polonizacją UJ przeszedł on jednak do Lwowa, a następnie do niemieckojęzycznego, nowo utworzonego uniwersytetu w Czerniowcach. Po nim stanowisko objął nauczyciel Gimnazjum św. Jacka w Krakowie Maksymilian Iskrzycki (bez doktoratu i habilitacji - jako profesor nadzwyczajny). Uzwyczajniono ją w $1878 \mathrm{roku}^{20}$. Praca badawcza nie była jednak jego głównym obszarem działań, skupiał się na dydaktyce i działaniach na rzecz kształcenia nauczycieli, będąc równocześnie dyrektorem Komisji Egzaminów Nauczycielskich w Krakowie.

W połowie lat 70. XIX wieku rozpoczął się znakomity okres z dziejach filologii klasycznej na UJ. Zapoczątkowały go odbyte w 1877 roku dwie habilitacje: Bronisława Kruczkiewicza oraz Kazimierza Morawskiego. Kruczkiewicz był wychowankiem UJ, Morawski natomiast to kolejny Wielkopolanin, który przybył do Krakowa po studiach berlińskich między innymi u Ernsta Curtiusa, Johanna Droysena i Theodora Mommsena. Morawskiego, który miał wówczas 25 lat, popierali: Józef Szujski, Stanisław Tarnowski i Michał Bobrzyński. Rada Wydziału po obszernym referacie Iskrzyckiego ${ }^{21}$ jednomyślnie uchwaliła wniosek o przekazaniu mu katedry nadzwyczajnej, w miejsce schorowanego Brandowskiego. W listopadzie 1877 roku wpłynął też wniosek Kruczkiewicza o habilitację, ale ze względu na różnicę w datach wniesienia podania habilitował się jako drugi. Tak więc w roku 1878 w Krakowie było dwóch profesorów i dwóch docentów filologii klasycznej. Morawski wykłady rozpoczął w roku akademickim 1880/1881, katedrę zwyczajną uzyskał w 1887 roku i od tej pory zaczęła się kształtować krakowska szkoła filologii klasycznej. Rezultaty prac badawczych Morawskiego są nie do przecenienia, a on sam ukształtował całe pokolenia latynistów polskich. Był wybitnym filologiem z zacięciem do historii kultury i wielkim znawcą polskiego humanizmu. Pisarz, poeta, publicysta i wspaniały orator to tylko kilka określeń, które najczęściej pojawiają się przy opisie jego postaci. Prowadził studia nad łacińskimi retorami, historią greckiej wymowy (od Gorgiasza

19 Pótwiekowe dzieje Kótka Filologicznego U.U.J. 1879-1929, Kraków 1930, s. 35.

20 W. Madyda, op. cit., s. 50.

${ }^{21}$ Archiwum Uniwersytetu Jagiellońskiego [dalej:Arch. UJ], Wydział Filozoficzny [dalej: WF] II 121. Teczka akt habilitacyjnych. Referat w sprawie habilitacji Kazimierza Morawskiego na docenta filologii klasycznej z 20 października 1877 roku. 
do Demostenesa), badał źródła epigraficzne do początków chrześcijaństwa w arystokratycznych rodach rzymskich, prowadził badania nad renesansem polskim. Do roku 1890 przewagę $\mathrm{w}$ jego pracach miała tematyka dotycząca studiów nad humanizmem w Polsce, czego zwieńczeniem była Historia Uniwersytetu Jagiellońskiego. W drugiej części swej naukowej twórczości skupiał się na wpływie retoryki na pisarzy epoki cesarstwa rzymskiego, stając się wybitnym znawcą topiki motywów retorycznych w poezji i prozie rzymskiej ${ }^{22}$. Zwieńczenie prac stanowiło monumentalne dzieło Historia literatury rzymskiej. Morawski potrafił doskonale wykorzystać zdobycze nauki niemieckiej, która go ukształtowała, dostrzegał znaczenie szkoły francuskiej, a jednocześnie działał i tworzył z ogromnym poczuciem misji narodowej ${ }^{23}$.

Dla dalszych losów krakowskiej filologii klasycznej istotne znaczenie miało obsadzenie katedry po śmierci hellenisty Maksymiliana Iskrzyckiego. Morawski widział na katedrze Adama Miodońskiego, który habilitował się w 1891 roku i który został ostatecznie następcą Iskrzyckiego. Miodoński, ulubiony uczeń Morawskiego, był - podobnie jak jego mistrz - latynistą i zajmował się późnorzymskim i wczesnochrześcijańskim piśmiennictwem oraz literaturą łacińsko-polską, współpracował też z Eduardem Wölfflinem ${ }^{24}$ przy jego Archiv für lateinische Lexikographie. Zalicza się do wybitnych uczonych, których pozycja międzynarodowa jest do dziś niepodważalna, a jego prace $\mathrm{z}$ zakresu gramatyki i językoznawstwa przywoływane są w opracowaniach obcojęzycznych. Zmarł jednak przedwcześnie na gruźlicę w 1913 roku. W czasie starań o katedrę rywalizował z Leonem Sternbachem, którego popierały władze oświatowe w Wiedniu. Sternbach studiował początkowo w Lipsku, a następnie w Wiedniu u Wilhelma Hartla ${ }^{25}$ (późniejszego ministra oświaty w latach 1900 1905). W 1886 roku w stolicy monarchii austro-węgierskiej wydano nagrodzoną rok wcześniej w Lipsku jego pracę Meletemata Graeca, poświęconą krytycznej analizie epigramów greckich i ich scholiom bizantyńskim. Jej wydanie uchodzi za początek polskiej bizantologii ${ }^{26}$. Trzy lata później (w 1889 roku) Sterbnach habilitował się we Lwowie u Ludwika Ćwiklińskiego, a w 1891 roku przeniósł habilitację do Krakowa ${ }^{27}$. Dzięki poparciu swojego wiedeńskiego profesora rok później otrzymał katedrę ad personam, a profesorem zwyczajnym został w 1897 roku. Jako pierwszy

22 S. Hammer, Kazimierz Morawski jako filolog i humanista (1852-1925), „Eos” R. 28, 1925, s. 238; K. Kraus, Kazimierz Morawski (1852-1925) [w:] Ztota Księga Wydzialu Filologicznego, s. 123125.

23 M. Plezia, Filologia klasyczna [w:] Historia nauki polskiej, t. IV: 1863-1918, cz. III, s. 733.

24 U. Dill, Eduard Wölfflin [w:] Historisches Lexikon der Schweiz, http://www.hls-dhs-dss.ch/ textes/d/D43464.php [dostęp: 12.09.2017].

${ }_{25}$ G. Baader, Wilhelm Hartel [w:] Neue Deutsche Biographie (NDB), Bd. 7, Berlin 1966, s. 707709; Wilhelm Hartel [w:] Österreichisches Biographisches Lexikon 1815-1950 (ÖBL), Bd. 2, Wien 1959, s. 192.

26 W. Ceran, Historia i bibliografia rozumowana bizantynologii polskiej (1800-1998), t. 1, Łódź 2001, s. 26.

27 Arch. UJ, WF II 121. Teczka akt habilitacyjnych. Leon Sternbach. Pismo Namiestnictwa z 7 grudnia 1891 roku do dziekana Wydziału Filozoficznego z informacją o zgodzie na przeniesienie habilitacji do Krakowa. 
w polskiej nauce prowadził poważne badania biznatologiczne ${ }^{28}$. Sternbach był fenomenalnym erudytą, wielkim znawcą rękopisów z zakresu piśmiennictwa greckiego, fascynowała go dokładna analiza tekstów, a ich wszechstronna egzegeza stanowiła dla niego istotę pracy filologa, dlatego też nie pozostawił po sobie żadnej syntezy. Jego dorobek naukowy niewątpliwie należy do największych osiągnieć filologicznych końca XIX i początku XX wieku na ziemiach polskich. Sternbach miał również ogromne zasługi jako wydawca tekstów. Po 1905 roku całkowicie oddał się pracy nad krytycznym wydaniem dzieł poety, pisarza i teologa z IV wieku Grzegorza z Nazjanzu $^{29}$. Jego uczniem był Jan Sajdak, który od 1916 roku działał na Uniwersytecie Lwowskim. O ile Sternbach koncertował się na bizantynistyce, o tyle kolejne pokolenie uczonych na UJ łączyło badania z zakresu hellenistyki z szeroko rozumianą latynistyką. Należeli do niego Tadeusz Sinko (habilitacja 1903), Jan Sajdak (habilitacja 1912) i Gustaw Przychocki (habilitacja 1913). Sinko w 1907 roku przeniósł się do Lwowa, gdzie został mianowany profesorem nadzwyczajnym, a pięć lat później otrzymał tytuł profesora zwyczajnego. Zakres jego wykładów obejmował hellenistykę, patrystykę i komparatystykę. Po śmierci Adama Miodońskiego w 1913 roku powrócił na UJ. Zainteresowania naukowe Sinki obejmowały hellenistykę, literaturę polsko-łacińską, poezję łacińską, a po I wojnie światowej także dzieje literatury polskiej. Podobnie jak Przychocki zaczynał od studiów nad Grzegorzem z Nazjanzu, później zajął się głównie poezją rzymską oraz średniowiecznym piśmiennictwem łacińskim. Karierę po 1918 roku kontynuował w Warszawie, by pod koniec okresu międzywojennego powrócić do Krakowa. Należy wspomnieć jeszcze o badaczach, którzy - pozostając poza katedrami filologicznymi - mieli na UJ wkład w rozwój badań nad piśmiennictwem starożytnym (ks. Stefan Pawlicki) albo których klasyczne filologiczne wykształcenie $\mathrm{z}$ powodzeniem umożliwiło działania w wyodrębniających się dziedzinach naukowych (Jan Rozwadowski - językoznawca, Piotr Bieńkowski - pierwszy archeolog klasyczny, 1897).

Filologię klasyczną w latach 50. XIX wieku na Uniwersytecie Lwowskim reprezentował Bernard Jülg, który studiował w Heidelbergu i Berlinie, a przed objęciem katedry był profesorem liceum w Rastatt. Od maja 1851 do grudnia 1852 roku jako profesor nadzwyczajny wykładał sanskryt oraz językoznawstwo ogólne, a także prowadził zajęcia $\mathrm{z}$ filologii klasycznej ${ }^{30}$. $\mathrm{Z}$ okresu lwowskiego nie pozostawił po sobie znaczniejszych prac naukowych, lecz można go uznać za pierwszego indoeuropeistę na tym uniwersytecie ${ }^{31}$. Jülg wykładał literaturę grecką, elementy „starożytności

28 W. Ceran, op. cit., s. 26.

29 Projekt wydania dzieła Grzegorza z Nazjanzu prowadzony był przez AU dzięki fundacji A. Cieszkowskiego. Poszukiwanie 1500 rękopisów z komentarzem filologicznym i historycznym było przedsięwzięciem kosztownym i bardzo czasochłonnym. Obok Sternabacha w tej inicjatywie brali udział T. Sinko, G. Przychocki i J. Sajdak. Kryzys finansowy AU po I wojnie światowej spowolnił tempo badań. Ostatecznie decyzją Komitetu Nauk o Kulturze PAN w 1952 r. wycofano się z projektu. $\mathrm{Z}$ planowanego wydawnictwa nie ukazał się ani jeden tom. Pozostało natomiast wiele studiów i opracowań.

30 H.M. Ölberg, Bernhard Jülg [w:] Neue Deutsche Biographie (NDB), Bd. 10, Berlin 1974, s. 642.

31 J. Smereka, Filologia klasyczna w Uniwersytecie Lwowskim do czasów Zygmunta Węclewskiego i Ludwika Ćwiklińskiego, Lwów 1937, s. 11. 
państwowych rzymskich", sanskryt, język mongolski, armeński i języki słowiańskie, prowadził ćwiczenia językowo-stylistyczne, interpretował wybrane fragmenty Mahabharaty (1952/1853) 32 . Po nim mianowano Wilhelma Kergla, wychowanka uniwersytetu we Wrocławiu, profesora z Ołomuńca, który powołany został głównie w celu prowadzenia części filologicznej seminarium filologiczno-historycznego dla nauczycieli gimnazjalnych ${ }^{33}$. W czasie pobytu we Lwowie pracował nad dziełami Ksenofonta, Tukidydesa i Tacyta oraz publikował poradniki dla nauczycieli języków klasycznych ${ }^{34}$. W prowadzonych wykładach interpretował i objaśniał autorów greckich i rzymskich. Koncentrował się jednak na hellenistyce i taką katedrę otrzymał w roku akademickim 1861/1862. Bardzo pracowity, wymagał od studentów wielu prac seminaryjnych z zakresu krytyki tekstu, ale też prac historyczno-literackich oraz językoznawczych i gramatycznych ${ }^{35}$.

W roku 1861 powstała we Lwowie druga katedra filologii klasycznej, którą objął po wyjeździe ze spolonizowanego uniwersytetu w Krakowie Gustaw Linker ${ }^{36}$. Studiował w Marburgu i Berlinie, habilitował się w Wiedniu i przez cztery lata wykładał w Krakowie. Był latynistą. Zajmował się głównie Salustiuszem, Cyceronem i Horacym, wykładał również historię starożytnego Rzymu. Ludwik Finkel w Historii Uniwersytetu Lwowskiego napisał, że ,uczniowie szanowali go dla jego wiedzy i bystrości, obawiali się jego srogości" ${ }^{37}$. W 1870 roku w związku z planowaną polonizacją Uniwersytetu Lwowskiego przeniósł się do Pragi. Jego następcą został Jan Wróbel, ostatni niemieckojęzyczny profesor, który przeszedł tu z Krakowa i pracował na Uniwersytecie Lwowskim do 1875 roku. W listopadzie 1872 roku katedrę po Kerglu objął Zygmunt Węclewski (który rywalizował o nią z Zygmuntem Samolewiczem, wychowankiem Uniwersytetu Lwowskiego), a w semestrze zimowym 1876/1877 po Wróblu jako profesor nadzwyczajny mianowanie otrzymał Ludwik Ćwikliński. Od tej pory obie katedry były w pełni spolonizowane.

Zygmunt Węclewski był pierwszym filologiem Polakiem na katedrze filologii klasycznej we Lwowie ${ }^{38}$. Z pochodzenia Wielkopolanin, po studiach we Wrocławiu i Halle wykładał w Szkole Głównej Warszawskiej. Na Uniwersytet Lwowski przyszedł już ze sporym dorobkiem naukowym, który znacznie rozwinął w trakcie piętnastoletniej działalności. Pracował nad słownikami łacińsko-polskim oraz grecko-polskim, a także ukończył tłumaczenia wszystkich utworów trójki dramaturgów greckich: Ajschylosa, Eurypidesa i Sofoklesa. Wydał ponadto Kronikę książat polskich w serii Monumenta Poloniae Historica oraz pamiętniki Jana Chryzostoma

32 Ibidem, s.14.

33 Ibidem, s. 11.

34 L. Finke1, S. Starzyński, Historia Uniwersytetu Lwowskiego, t. 1, Lwów 1894, s. 320.

35 J. Smereka, Filologia klasyczna..., s. 16.

36 C. Haeberlin, Gustav Linker [w:] Allgemeine Deutsche Biographie (ADB), Bd. 52, Leipzig 1906, s. 1-2.

37 L. Finkel, S. Starzyński, op. cit., s. 321.

38 K. Królczyk, Polscy badacze starożytności na Uniwersytecie Lwowskim (1873-1939) - szkic do portretu [w:] Haec mihi in animis vestris templa. Studia Classica in Memory of Professor Lestaw Morawiecki, red. P. Berdowski, B. Balahaczek, Rzeszów 2007, s. 24. 
Paska $^{39}$. Opracował też studium poświęcone wybitnemu filologowi wileńskiemu Gotfrydowi Grodkowi. Jego wykłady obejmowały kwestie historyczno-literackie, zagadnienia gramatyczne oraz dzieje Greków i Rzymian. Zmarł w roku 1887. Po śmierci Węclewskiego profesorem nadzwyczajnym w 1888 roku mianowano Bronisława Kruczkiewicza ${ }^{40}$. Był on wychowankiem uniwersytetu krakowskiego, gdzie uzyskał doktorat (1872) i habilitację (1877). Po krótkim pobycie we Lwowie (był tam docentem prywatnym) w 1881 wrócił do Krakowa, by następnie znów (w latach 1888-1916) działać na Uniwersytecie Lwowskim. W swych wykładach skupiał się na epigrafice, religii, ustroju, wojskowości rzymskiej, topografii Rzymu, składni, stylistyce łacińskiej i historii literatury rzymskiej ${ }^{41}$. Przykładał dużą wagę do praktycznego przygotowania słuchaczy w zakresie rozbioru krytycznego utworó $\mathrm{w}^{42}$. W pracach naukowych pisał o Tacycie i Enniuszu, był autorem popularnego i wznawianego słownika łacińsko-polskiego dla szkół średnich oraz - podobnie jak właściwie wszyscy filologowie klasyczni tego okresu - podejmował badania nad autorami epoki renesansu, polskimi i obcymi.

Ludwik Ćwikliński, który dołączył do składu uniwersytetu lwowskiego w 1876 roku, podobnie jak Węclewski pochodził z Wielkopolski - z Gniezna. Studiował we Wrocławiu i w Berlinie u Droysena i Mommsena. Tytuł doktorski uzyskał w Berlinie w 1873 roku. Gdy powoływano go na katedrę nadzwyczajną we Lwowie (zresztą z pominięciem habilitacji), miał zaledwie 23 lata. Katedrę zwyczajną uzyskał w wieku 26 lat. Zakres jego zainteresowań był bardzo szeroki - badał historiografię i poezję grecką, interesowała go zwłaszcza Wojna peloponeska Tukidydesa, a także Ksenofont i Herodot. Komentował odkrycia archeologiczne Heinricha Schliemanna, pisał podręczniki do gramatyki greckiej oraz zajmował się literaturą polsko-łacińską ${ }^{43}$. Prowadzone przez niego wykłady obejmowały zarówno elementy historyczno-literackie, jak i historyczne oraz językoznawcze. Był twórcą powstałego we Lwowie Towarzystwa Filologicznego (1893) oraz jego organu „Eos” (1894), który stał się głównym forum filologicznym na ziemiach polskich. Do roku 1902 działał na Uniwersytecie Lwowskim, następnie przeniósł się do Wiednia, gdzie skupił się głównie na pracy w Instytucie Archeologicznym oraz w Ministerstwie Wyznań i Oświaty,

39 J. Smereka, Pierwszy filolog-Polak w Uniwersytecie Jana Kazimierza - Zygmunt Węclewski. W 50-ta rocznice śmierci, „Eos” R. 39, 1938, z. 2, s. 217-238.

40 K. Królczyk, Polscy badacze..., s. 28.

41 Ibidem.

42 Arch. UJ, WF II 121. Teczki akt habilitacyjnych. Podanie Bronisława Kruczkiewicza o posadę docenta filologii klasycznej z 5 lipca 1877 roku.

43 K. Królczyk, Polscy badacze..., s. 26-28; idem, Ludwik Ćwikliński (1853-1942), „Nowy Filomata" R. 14, 2010, z. 2, s. 83-94; idem, Ludwik Ćwikliński (1853-1942) - lwowski uczony, działacz spoteczny i polityk drugiej połowy XIX wieku [w:] Історична пам>ять украӥнців і поляків у період формування начіональної свідомості в XIX-першій половині XX століття, red. L. Zaszkilniak, J. Pisulińska, P. Sierżęga, Lviv 2011, s. 96-114; K. Kumaniecki, Ludwik Ćwikliński, „Pamiętnik Literacki” R. 36, 1946, s. 96-103; T. Sinko, Ludwik Ćwikliński, „Kwartalnik Historyczny” R. 53, 1939-1945, s. 463-468; S. Pilch, Ludwik Ćwikliński. 80-lecie urodzin i diamentowe gody z nauka, „Kwartalnik Klasyczny” R. 7, 1933, z. 4, s. XV-XLIV. 
gdzie otrzymał stanowisko ministra ${ }^{44}$. Po jego odejściu profesorem nadzwyczajnym mianowano Stanisława Witkowskiego, który studia ukończył na UJ, tam też uzyskał doktorat, a habilitację zrobił już we Lwowie w 1898 roku z zakresu papirologii. Jego profesurę uzwyczajniono w 1905 roku, a w stan spoczynku przeszedł w 1935 roku. Był wybitnym hellenistą i pierwszym polskim papirologiem. Przez krótki okres z uniwersytetem we Lwowie związani byli również Tadeusz Sinko (w latach 19071913 trzeci profesor zwyczajny z filologii klasycznej) oraz Jan Sajdak wykładający od 1917 do 1919 roku po Kruczkiewiczu. Jako docent prywatny od 1895 roku prowadził zajęcia (ucząc jednocześnie w IV, a następnie V Gimnazjum we Lwowie) Michał Jezienicki, wychowanek Uniwersytetu Lwowskiego. Studia odbył w Paryżu i Berlinie u Adolfa Kirchhoffa, gdzie skupiał się na interpretacji dzieł pisarzy greckich i rzymskich. Nie udało mu się uzyskać katedry po Ćwiklińskim, więc zdecydował się na karierę w oświacie i w 1906 roku został dyrektorem gimnazjum polskiego w Stanisławowie ${ }^{45}$. Archeologię klasyczną reprezentował na lwowskiej uczelni Jan Hadaczek, który habilitował się w 1903 roku.

W obu ośrodkach akademickich w dziedzinie filologii klasycznej w pełni zastosowano metody badania historycznego, znacznie powiększono zakres wiedzy, którą traktowano głównie opisowo. Poszerzono bazę źródłową o inskrypcje, papirusy, piśmiennictwo wczesnochrześcijańskie. Na tej podstawie wykształciły się bizantynistyka i archeologia śródziemnomorska. Opracowano model edycji tekstów oparty na możliwie pełnym zestawie rękopisów i poznaniu ich historiii ${ }^{46}$. Tworząc katedry, najpierw zatrudniano badaczy niemieckich, następnie wychowanków niemieckich uczelni (pochodzących głównie z Wielkopolski), by ostatecznie stworzyć polskie środowisko z obsadami katedr już z rodzimych habilitacji. Na obu galicyjskich uniwersytetach funkcjonowały po trzy katedry filologii klasycznej. Badania często miały charakter dwu- lub trzytorowy. Zajmowano się analizą, tłumaczeniami i edycją tekstów starożytnych, łacińskich i greckich. Powstawały też studia dotyczące prac $\mathrm{z}$ zakresu piśmiennictwa łacińskiego z czasów średniowiecza i renesansu. W ośrodku krakowskim rozpoczęto szeroki program badań nad tekstami wczesnochrześcijańskimi, dzięki czemu wyodrębniła się bizantynistyka. Skonsolidowało się również środowisko wokół Towarzystwa Filologicznego i pisma „Eos”. Powołano także samodzielną Komisję Filologiczną przy Akademii Umiejętności. Niewątpliwie filologia klasyczna przeżywała wtedy swój złoty okres. Niemiej jednak pewne różnice pomiędzy uczelniami były widoczne. W Krakowie już w drugiej połowie lat 70. XIX wieku habilitował się Kazimierz Morawski, tworząc krakowską szkołę filologii klasycznej, do której w kolejnym pokoleniu należeli: Adam Miodoński, Tadeusz Sinko, Jan Sajdak czy Gustaw Przychocki. Katedry krakowskie były bardziej stabilne, szybciej wyodrębniały się też kolejne specjalizacje. Lwów, dzięki sprawności organizacyjnej

44 Kwestie innych działań organizacyjnych na rzecz uczelni i środowiska filologicznego zostały pominięte, gdyż zagadnienia te wykraczają poza tematykę niniejszej pracy.

45 Śp. Dr. Michat Jezienicki 1859-1935, „Eos” R. 36, 1935, s. 477-480; Michat Jezienicki, „Przegląd Klasyczny” R. 2, 1936, z. 2, s. 151-155.

46 M. Plezia, Filologia klasyczna [w:] Historia nauki polskiej, t. IV: 1863-1918, cz. III, s. 726. 
Ćwiklińskiego, dał z kolei podstawy do tworzenia i konsolidowania ogólnopolskiego środowiska naukowego.

\section{FILOLOGIE NOWOŻYTNE}

Nowy typ szkół średnich wymagał odpowiednio wykształconych nauczycieli, zwłaszcza że program gimnazjalny przewidywał naukę języka niemieckiego w wymiarze od czterech do sześciu godzin tygodniowo (przez osiem lat). Właściwie przez cały okres autonomiczny rezultaty nauczania języka niemieckiego w szkołach średnich uważano za mierne. Kształcenie i dokształcanie nauczycieli tego przedmiotu było więc ważnym elementem polityki władz oświatowych w Wiedniu. Starano się fundować stypendia i nagrody za prace seminaryjne dla studentów oraz stypendia na wyjazdy dokształcające. Powołane katedry dzięki osobowościom profesorów stały się jednak ośrodkami przede wszystkim naukowymi, choć działania poszczególnych naukowców miały różnorodny charakter. W Krakowie katedra germanistyki powstała w roku akademickim 1850/1851. Podobnie jak powołanie drugiej katedry filologii klasycznej miała ona służyć przede wszystkim celom utylitarnym. Objął ją wrocławianin Karol Weinhold jako profesor nadzwyczajny języka i literatury niemieckiej. Studiował we Wrocławiu i Berlinie, habilitację uzyskał w Halle w $1847 \mathrm{roku}^{47}$. Zajmował się dialektologią, historią kultury i literatury niemieckiej, w Krakowie starał się o zbudowanie podstawowej bazy dydaktycznej w postaci biblioteki, ale po pożarze miasta w 1850 roku, w którym stracił część swoich rękopisów i zbiorów, w sumie po zaledwie kilkumiesięcznym pobycie w Krakowie uzyskał przeniesienie na własną prośbę do $\mathrm{Grazu}^{48}$. Po nim katedrę objął Morawianin František Tomáš Bratránek, augustianin, który studiował w Wiedniu. Poznał tam synową Johanna Wolfganga Goethego Otylię i dzięki niej wszedł w środowisko intelektualne Wiednia. Po krótkim pobycie w klasztorze został asystentem profesora filozofii na Uniwersytecie Lwowskim Ignacego Hanuša, a następnie nauczycielem w gimnazjum we Lwowie. Nie porzucił habitu, ale działał również poza klasztorem. W 1850 roku wydał w Brnie Handbuch der deutschen Literaturgesichte, co dało mu przepustkę na katedrę w Krakowie, gdzie od 1851 roku był profesorem nadzwyczajnym, a od 1853 - zwyczajnym $^{49}$. Przez 30 lat działalności na UJ zyskał niezwykłą popularność ze względu na wysoki poziom i atrakcyjność wykładów. Jego badania obejmowały zarówno historię literatury oraz języka niemieckiego, jak i stylistykę, poetykę i mitologię. Zajmował się szczególnie romantyzmem niemieckim, a zwłaszcza Goethem, wydając jego korespondencję. Przekładał na język niemiecki poetów polskich, popularyzując ich

${ }^{47}$ O. Dobijanka-Witczakowa, Historia Katedry Germanistyki w Uniwersytecie Jagiellońskim [w:] Wydziat Filologiczny Uniwersytetu Jagiellońskiego, s. 350-352.

48 Eadem, s. 350-351.

49 O. Dobijanka-Witczakowa, František Tomáš Bratránek [w:] Ztota Ksiega Wydziału Filologicznego, s. 52. 
poza obszarem Galicji. Cenił sobie zwłaszcza Wincentego Pola, tłumaczył również pisma historyczne Józefa Szujskiego ${ }^{50}$. W styczniu 1882 roku przeszedł na emeryturę. Uważany jest za jednego z najwcześniejszych poważnych badaczy twórczości Goethego. Docenia się zwłaszcza świetnie wydaną korespondencję ${ }^{51}$. Jego uczniami byli Stanisław Tarnowski oraz germanista Karol Petelenz.

Po odejściu Bratránka zebrała się specjalna komisja mająca wyłonić odpowiedniego kandydata na wakującą katedrę. Miał to być wybitny specjalista - germanista władający językiem polskim, z bardzo dobrą znajomością literatur i języków nowożytnych. Nie znaleziono go wśród uczonych polskich i ostatecznie katedrę zaproponowano Wilhelmowi Creizenachowi z Lipska pod warunkiem opanowania przez niego w ciągu dwóch lat języka polskiego ${ }^{52}$. Creizenach pochodził z Frankfurtu, studiował w Halle i w Lipsku literaturę i języki germańskie oraz romańskie. W tym ostatnim mieście uzyskał doktorat, następnie kontynuował studia we Frankfurcie, Jenie i Wrocławiu. Ostatecznie habilitował się w Lipsku i tam wykładał historię literatury nowożytnej. W roku 1882 przebywał w Paryżu ${ }^{53}$. Rok później został mianowany profesorem nadzwyczajnym (od 1886 był profesorem zwyczajnym) we Lwowie i przez 30 lat kierował katedrą. $Z$ jego inicjatywy w 1885 roku powstało Seminarium Germanistyczne, a w 1900 roku studenckie naukowe Koło Filologiczne Niemieckie $^{54}$. Należał do wybitnych poliglotów, znał języki germańskie, klasyczne, romańskie i słowiańskie. Był badaczem cenionym powszechnie w Europie, rozgłos przyniosło mu zwłaszcza pięciotomowe dzieło Geschichte des neuren dramas (Halle 1893). Także on wiele prac poświęcił twórczości Goethego, ponadto opracował liczne biografie pisarzy niemieckich, zwłaszcza z XVIII wieku. Pisał i publikował również po polsku. Jego wykłady, poza historią literatury niemieckiej, obejmowały też twórczość Williama Shakespeare'a, gramatykę historyczną języka niemieckiego oraz historię literatury średniowiecznej i siedemnastowiecznej ${ }^{55}$. Doktoryzowało się ponad 40 jego uczniów. Byli wśród nich germaniści Adam Kleczkowski i Jan Berger, anglista Roman Dyboski oraz wielu nauczycieli gimnazjalnych, którzy z wielkimi sukcesami łączyli pracę dydaktyczną i naukową. Po odejściu Creizenacha do lipca 1914 roku katedra nie była obsadzona. Ze względu na jego znaczny dorobek naukowy zdecydowano się powołać na wakującą katedrę, jako profesora nadzwyczajnego, Spiridiona Wukadinovićia, który habilitował się w Pradze w 1907 roku z zakresu nowszej literatury i języka niemieckiego. W badaniach skupiał się na twórczości

50 Eadem, Historia Katedry Germanistyki..., s. 350-351.

${ }^{51}$ Badaczem twórczości naukowej T. Bratranka był Jaromír Loužil, który poświęcił mu liczne prace i dokonał edycji części tekstów: J. Loužil, F.T. Bratraneks Leben und Philosophie, „Bohemia. Jahrbuch des Collegium Carolinum”, Bd. 13, München-Wien 1972; idem, Franz Thomas Bratranek (1815-1884) [w:] Wegbereiter der deutsch-slawischen Wechselseitigkeit, ed. E. Winter, G. Jarosch, Berlin 1983; idem, Franz Thomas Bratraneks Beitrag zum Aldalbert - Stifter - Verständnis, „Philologica Pragensia” 1990, vol. 33, č. 1, s. 20-28.

52 K. Lipiński, Wilhelm Creizenach (1851-1919) [w:] Złota Księga Wydziału Filologicznego, s. 110 .

53 O. Dobijanka-Witczakowa, Historia Katedry Germanistyki, s. 350-353.

54 Ibidem, s. 356.

55 Ibidem, s. 354. 
Kleista, Grabbego, Goethego i Sonnenberga ${ }^{56}$. Obok niego (w czasie I wojny światowej) działał także Zygmunt Łempicki (habilitacja w1916 roku) prowadzący wykłady i ćwiczenia $\mathrm{z}$ historii literatury niemieckiej i gramatyki historycznej języka niemieckiego. W 1919 roku przeniósł się na Uniwersytet Warszawski ${ }^{57}$.

We Lwowie, podobnie jak w Krakowie, katedrę języka i literatury niemieckiej utworzono na początku lat 50. Otrzymał ją na mocy postanowienia z 3 września 1851 roku Jan Hloch, profesor gimnazjalny, który dopiero w 1865 roku uzyskał tytuł profesora zwyczajnego. Nie prowadził aktywnej działalności naukowej i pozostawał na katedrze do roku 1871. Ludwik Finkel określił go jednoznacznie: „człowiek bardzo miernych zdolności, [...] wpływu żadnego nie miał i przeszedł bez znaczenia" ${ }^{58}$. Jego następcą został Eugeniusz Janota, niegdyś ksiądz katolicki, potem pastor, nauczyciel Gimnazjum św. Anny, który w tym czasie był jedynym Polakiem - profesorem germanistyki. Nominację na profesora nadzwyczajnego uzyskał w 1871 roku, a na zwyczajnego - dwa lata później. Jako praktyk wiele prac poświęcił nauczaniu języka niemieckiego. Wydał Gramatykę języka niemieckiego, Wypisy niemieckie dla pierwszej i drugiej klasy gimnazjalnej, Wypisy niemieckie dla trzeciej i czwartej klasy gimnazjalnej oraz publikacje poświęcone badaniom nad językiem niemieckim i jego narzeczami. Z zamiłowania taternik i zwolennik ochrony przyrody, był współtwórcą Towarzystwa Tatrzańskiego i niewątpliwie niebanalną postacią tego okresu. Zmarł w 1878 roku. Wykłady po nim zaczął prowadzić August Sauer ${ }^{59}$. Studiował on w Wiedniu i Berlinie, gdzie w roku 1877 uzyskał tytuł doktorski. Habilitował się w Wiedniu w 1879 roku $^{60} \mathrm{i}$ bezpośrednio po tym rozpoczął pracę we Lwowie jako zastępca profesora. W 1883 roku przeniósł się do Grazu, a następnie do Pragi ${ }^{61}$. Badał głównie okres romantyzmu niemieckiego, zajmował się również edycją tekstów i podczas pobytu we Lwowie ogłosił drukiem kilka prac z tego zakresu. W roku akademickim 1883/1884 po Sauerze wykłady przejął (jako profesor nadzwyczajny) Ryszard Maria Werner, z pochodzenia Morawianin. Studiował w Wiedniu, Berlinie i Strassburgu, a habilitował się w Grazu ${ }^{62}$. W 1886 roku został zwyczajnym profesorem literatury i języka niemieckiego we Lwowie, gdzie prowadził badania historyczno-literackie oraz był współautorem podręcznika do języka niemieckiego dla galicyjskich szkół średnich, przygotowanego wspólnie z Karolem Petelenzem. Wiele prac poświęcił Goethemu, Gottholdowi Lessingowi oraz Fridrichowi Hebblowi. Był autorem obszernej pracy poświęconej rozwojowi poematu Lyrik und Lyriker (1890). Napisał również: Ludwig Philipp Hahn. Ein Beitrag zur Geschichte der Sturm- und Drangzeit (1877), Vollendete und Ringende. Dichter und Dichtungen der Neuzeit (1900), Hebbel, ein Lebensbild (1904), Gotthold Ephraim Lessing (1908), Deutsche

\footnotetext{
56 Ibidem, s. 358.

57 Ibidem.

58 L. Finke1, S. Starzyński, op. cit., s. 322.

59 S. Jordan, August Sauer [w:] Neue Deutsche Biographie (NDB), Bd. 22, Berlin 2005, s. 451.

60 R. Pich1, August Sauer [w:] Österreichisches Biographisches Lexikon 1815-1950 (ÖBL), Bd. 9,

${ }^{61}$ L. Finkiel, S. Starzyński, op. cit., s. 165-166.

62 Ibidem, s. 258-262.
} Wien 1988, s. 438. 
Dichter und Denker der Neuzeit (1914). Werner współpracował z czasopismami „Internationale Litteraturberichte”, „Monatsschrift für neue Literatur und Kunst”, „Jahresberichte für neue deutsche Litteraturgeschichte" i wieloma innymi. Maksymilian Kawczyński w 1881 roku po nieudanych staraniach o habilitację na $\mathrm{UJ}^{63}$ rok później uzyskał veniam legendi na Uniwersytecie Lwowskim z filologii niemieckiej. W 1888 roku rozszerzył ją na filologię romańską. Należał do wychowanków słynnego Gimnazjum św. Marii Magdaleny w Poznaniu, studiował w Lipsku, Zurychu i we Lwowie. Jako docent prywatny na uniwersytecie we Lwowie publikował głównie po polsku. Zakres tematyczny jego prac był bardzo szeroki i obejmował pedagogikę, kwestie gramatyki niemieckiej oraz literatury niemieckiej i francuskiej (w wypadku tej ostatniej w porównaniu z polską). Z jego niemieckich prac za najważniejszą należy uznać rozprawę doktorską z Lipska Studien zur Literaturgeschichte des XVIII Jahrhunderts z 1880 roku. Po okresie lwowskim od 1892 roku kontynuował karierę jako profesor romanistyki w Krakowie. W marcu 1905 roku na Uniwersytecie Lwowskim profesorem nadzwyczajnym dawnego języka niemieckiego i literatury mianowano Josepha Schatza, docenta prywatnego z Innsbrucka, który w 1911 roku uzyskał stanowisko profesora zwyczajnego, a rok później powrócił do Innsbrucka ${ }^{64}$. Był on znawcą języka starogermańskiego oraz dialektologiem. W czasie pobytu we Lwowie zajmował się głównie pracami nad twórczością Oswalda von Wolkensteina - XIV-wiecznego poety i dyplomaty związanego $z$ dworem Zygmunta Luksemburczyka ${ }^{65}$. Prowadził zajęcia $\mathrm{z}$ historii literatury niemieckiej i gramatyki oraz kierował seminarium germanistycznym $^{66}$.

W 1912 roku na profesora nadzwyczajnego powołano Viktora Dollmayra, Austriaka, który naturalizował się i pozostał we Lwowie do 1939 roku. Zajmował się głównie literaturą staroniemiecką ${ }^{67}$. Od roku akademickiego 1914/1915 docentem prywatnym został Emil Petzold, uczeń Wernera ${ }^{68}$. Uzyskał on doktorat w 1897 roku, pracował jako nauczyciel w gimnazjach galicyjskich, głównie lwowskich, nauczał również w Wyższej Szkole Przemysłowej we Lwowie, habilitował się z filologii germańskiej w 1914 roku i wykładał do roku 1920. Był współautorem wielu podręczników do nauki języka niemieckiego, współpracował przy tworzeniu podręczników Mariana Reitera Czytania polskie dla klasy I-III szkót średnich (Lwów 1910-1912),

${ }_{63}$ Arch. UJ, WF II 121. Teczki akt habilitacyjnych. Maksymilian Kawczyński. Podanie z 10 lipca 1881 roku.

${ }^{64}$ P. Wiesinger, Joseph Schatz (1871-1950) Sprachwissenschaftler, Dialektologe und Philologe an der Universitäten Innsbruck und Lemberg, „Вісник Львівського Університету”, Серія історична, Випуск 49, Львів 2013, s. 357.

${ }_{65}$ M. Hornung, Josef Schatz [w:] Österreichisches Biographisches Lexikon 1815-1950 (ÖBL), Bd. 10, Wien 1994, s. 45.

${ }^{66}$ C.K. Uniwersytet im. Cesarza Franciszka I we Lwowie. Program wykladów w pótroczu zimowym 1910/1911, Lwów 1910, s. 17; C.K. Uniwersytet im. Cesarza Franciszka I we Lwowie. Program wykładów w pótroczu letnim 1910/1911, Lwów 1911, s. 17.

${ }_{67}$ C.K. Uniwersytet im. Cesarza Franciszka I we Lwowie. Sklad Uniwersytetu w roku akademickim 1913/1914, Lwów 1913, s. 28.

${ }_{68}$ C.K. Uniwersytet im. Cesarza Franciszka I we Lwowie, Sklad Uniwersytetu w roku akademickim 1914/1915, Lwów 1914, s. 33. 
Ludomiła Germana, Karola Petelenza i Stanisława Gayczaka Ćwiczenia niemieckie dla klasy I-IV szkót średnich (wyd. 5-8, oprac. K. Petzold, Lwów 1916-1919) oraz Juliusza Ippoldta Deutsches Lesebuch für die oberen Klassen der galizischen Mittelschulen (Lwów 1918-1919) ${ }^{69}$.

Lata 90. na obu uczelniach były okresem powoływania nowych katedr z zakresu języków nowożytnych. Na UJ tradycje nauczania języka francuskiego i badań nad nim istniały już od XVIII wieku ${ }^{70}$. Formalne powołanie katedry nastąpiło dopiero w 1892 roku i objął ją wspomniany już wyżej Maksymilian Kawczyńskii ${ }^{71}$. Starał się on o posadę w Krakowie po profesorze Bratranku, ale wówczas nie udało mu się jej uzyskać. Równocześnie Creizenach dążył do stworzenia w Krakowie katedry romanistyki, mając na uwadze konkretnego kandydata - Emila Freymonda, który jednak po habilitacji w Heidelbergu w 1883 roku właśnie tam otrzymał katedrę ${ }^{72}$. Po kilku nieudanych próbach oraz wysłaniu Edwarda Porębowicza na studia zagraniczne rada Wydziału Filozoficznego zwróciła się do Kawczyńskiego, który przyjął propozycję. Profesorem zwyczajnym został w 1895 roku i kilka lat później zapoczątkował seminarium romanistyczne. Jego działalność naukowa koncentrowała się wokół historii literatury francuskiej okresu średniowiecza. Wykłady prowadził z całości historii literatury oraz z językoznawstwa romańskiego. Wykładał gramatykę historyczną i opisową prowansalską, włoską oraz hiszpańską, a także prowadził krytyczne interpretacje tekstów romańskich ${ }^{73}$. Choroba uniemożliwiła mu pracę w 1905 roku (zmarł rok później). Zastępcą Kawczyńskiego został Eugeniusz Herzog, docent Uniwersytetu Wiedeńskiego, który przebywał w Krakowie tylko trzy lata. W roku akademickim 1909/1910 habilitował się i został docentem Stanisław Stroński ${ }^{74}$. Studiował on we Lwowie u Porębowicza, wykształcenie uzupełnił podczas pobytu na Uniwersytecie Wiedeńskim i na Sorbonie. W 1911 roku został profesorem nadzwyczajnym i do wybuchu wojny prowadził wykłady oraz seminarium. W czasie wojny jako poddany rosyjski został internowany (konfinowany) w Austrii i na katedrę powrócił dopiero w 1917 roku. Prowadził wykłady wyłącznie z mediewistyki romańskiej. Na UJ pozostał do roku 1921, koncentrując się na szczegółowych badaniach dotyczących tekstów poetów staroprowansalskich, za które był bardzo ceniony ${ }^{75}$.

We Lwowie powstanie pierwszej katedry romanistycznej związane było z postacią wychowanka krakowskiego uniwersytetu Edwarda Porębowicza, który następnie prowadził studia romanistyczne, germanistyczne i anglistyczne w Berlinie,

${ }^{69}$ W. Bieńkowski, Emil Petzold, http://www.ipsb.nina.gov.pl/a/biografia/emil-petzold [dostęp: 12.08.2017].

70 H. Barycz, U narodzin uniwersyteckiego studium filologii romańskiej w Polsce, „Przegląd Historyczno-Oświatowy" 1961, z. 1, s. 3-16.

${ }_{71}$ U. Perkowska, Corpus Academicorum Facultatis Philosophiae Universitatis Iagellonicae 1850-1945, Kraków 2007, s. 152-153.

72 A.M. Kalkhoff, Romanische Philologie im 19. und frühen 20. Jahrhundert. Institutionengeschichtliche Perspektiven, Tübingen 2010, s. 41.

73 Z. Czerny, Filologia romańska w Uniwersytecie Jagiellońskim [w:] Wydziat Filologiczny Uniwersytetu Jagiellońskiego, s. 317.

74 Ibidem, s. 318.

75 Ibidem. 
Monachium, Montpellier, Barcelonie i Florencji, a doktoryzował się w Wiedniu w 1890 roku. Wykładał historię literatury powszechnej na Wyższych Kursach dla Kobiet Adriana Baranieckiego w Krakowie oraz pracował w Bibliotece AU. W latach 1893-1895 był bibliotekarzem w Bibliotece Polskiej w Paryżu. Jego lwowską habilitację zatwierdzono w październiku 1895 roku. Dwa lata później (28 XI 1899) uzyskał stanowisko profesora nadzwyczajnego, a w 1907 zwyczajnego. Był doskonałym tłumaczem z zacięciem poetyckim. Ogłosił przekłady: Don Juana Byrona (Warszawa, 1885), Wyboru pism wierszem i proza Leopardiego (Warszawa, 1887), Dramatów Calderona (Warszawa, 1887), Antologii prowansalskiej (Warszawa, 1887), Straconych zachodów mitosnych i komedii Wszystko dobre, co kończy się dobrze Shakespeare'a (Warszawa, 1895-1896), Boskiej komedii Dantego (Warszawa, 1899-1906) oraz uznawanych za jego najważniejsze osiągnięcie w zakresie przekładu Pieśni ludowych celtyckich, germańskich, romańskich (Lwów, 1909). Miał w swoim dorobku także prace popularnonaukowe o św. Franciszku z Asyżu (Warszawa, 1899) i o Dantem (Lwów, 1906). Pozostawił znakomite rozprawy: Andrzej Morsztyn, przedstawiciel baroku w poezji polskiej (Kraków, 1893), Studia do dziejów literatury średniowiecznej (Lwów, 1904), Nowe piękno wieków średnich (Lwów, 1916) ${ }^{76}$ oraz Teorię średniowiecznej miłości dwornej („Pamiętnik Literacki” 1904) ${ }^{77}$.

UJ miał także wieloletnie tradycje nauczania języka angielskiego. Uczono go już w latach 1818-1833, a w sposób ciągły lektoraty prowadzono od 1883 roku. Niestety nie zrealizowano wówczas planów rozpoczęcia wykładów z języka i literatury angielskiej ${ }^{78}$, a wyodrębnienie katedry filologii angielskiej nastąpiło bardzo późno. Ważną rolę w kształtowaniu tej dyscypliny odegrał Wilhelm Creizenach germanista, który włączył historię dramatu angielskiego do swoich badań. Był on promotorem pierwszego doktoratu anglistycznego obronionego w 1909 roku przez Andrzeja Tretiaka. Za właściwego twórcę katedry uznaje się jednak Romana Dyboskiego. Do wprowadzenia nowej specjalności w Krakowie przygotowywał się przez szerokie studia neofilologiczne w Wiedniu pod kierunkiem Jacoba Schippera, jednego z najwybitniejszych anglistów tej epoki. Podczas pobytu w Anglii studiował także w Londynie, Oxfordzie i Cambridge ${ }^{79}$, habilitował się w Wiedniu, a potem uzyskał przeniesienie habilitacji do Krakowa ${ }^{80}$, gdzie w roku akademickim 1908/1909 rozpoczął wykłady - najpierw jako docent, a od 1911 roku jako profesor nadzwyczajny dając $\mathrm{w}$ ten sposób początek anglistyce na ziemiach polskich ${ }^{81}$. W 1914 roku Wydział Filozoficzny wnioskował o mianowanie go profesorem zwyczajnym, ale zabiegi te

76 A. Biernacki, Edward Franciszek Porębowicz (1862-1937) [w:] PSB, t. 27, 1982-1983, s. 648 652; S. Glixelli, Ś.p. Edward Porębowicz, „Pamiętnik Literacki” R. 34, 1937, nr 1-4, s. 374-377.

77 S. Glixelli, op. cit.

${ }_{78}$ P. Mroczkowski, Historia Katedry Filologii Angielskiej w Uniwersytecie Jagiellonskim [w:] Wydziat Filologiczny Uniwersytetu Jagiellońskiego, s. 337.

79 Arch. UJ, WF II 121. Teczki akt habilitacyjnych. Roman Dyboski. Pismo R. Dyboskiego do Rady Wydziału Filozoficznego o uznanie veniam legendi z Wiednia z 1 czerwca 1908 roku.

80 Ibidem. Pismo MWiO z 27 sierpnia 1908 roku.

81 Arch. UJ, WF II 161, Pismo MWiO z 9 maja 1911 roku do Dziekanatu UJ w sprawie mianowania profesorem nadzwyczajnym docenta prywatnego Romana Dyboskiego. 
przerwał wybuch wojny (stało się to dopiero w 1920 r.). Dyboski do I wojny światowej dał się poznać jako świetny edytor tekstów (Songs, carols and other miscellaneous poems, London 1908) oraz jako świetny filolog ze zdolnościami do syntezy (Literatura i język średniowiecznej Anglii wydana w 1910 r. to pierwsza polska synteza historii literatury angielskiej do XV w. ${ }^{82}$ ). Długoletnim lektorem był Paweł Postel, jego zajęcia w semestrze zimowym miały formę dwóch kursów. Prowadził on kurs niższy języka angielskiego (dwa razy w tygodniu po jednej godzinie) oraz wyższy (w tym samym wymiarze). W semestrze letnim kontynuował kurs niższy oraz proponował lekturę wybranych ustępów prozy angielskiej, a także prowadził repetytorium z gramatyki języka angielskiego ${ }^{83}$. Studenci mogli uczestniczyć w tych zajęciach bezpłatnie. Drugim lektorem był Fryderyk Wilhelm Robertson Butler ${ }^{84}$, który zimą prowadził zajęcia The Englisch Lake Poets (również dwa razy w tygodniu po godzinie) ${ }^{85}$, a w semestrze letnim Popular English Poems ${ }^{86}$. Proponował też zajęcia poświęcone utworom Szekspira (Shakespeare’s Hamlet, Shakespeare: selected) ${ }^{87}$. Katedra została powołana dopiero w 1922 roku dla Władysława Tarnawskiego ${ }^{88}$.

Bilans zysków okresu drugiej połowy XIX wieku i początku wieku XX zamyka się dla uniwersytetów lwowskiego i krakowskiego w sumie sześcioma katedrami filologii klasycznej, rozwijającymi się katedrami germanistyki, od lat 90. także romanistyki, jak również narodzinami anglistyki. Na ich przykładzie widać wpływ, jaki miały odgórne reformy, które stanowiły bodziec do powstawania kolejnych katedr, oraz ewolucja w samych badaniach, a także zmiana akcentów w zainteresowaniach badawczych uczonych z języków klasycznych na filologie nowożytne. Podstawą działań naukowców były wykłady wyraźnie ukierunkowane na potrzeby nauczycieli, dające gruntowną wiedzę filologiczną, oraz ćwiczenia seminaryjne, w których na podstawie własnych, oryginalnych prac kształtowali warsztat analizy językowej i historyczno-literackiej studentów. Związki ze szkolnictwem średnim były widoczne w życiorysach w omawianym okresie zwłaszcza w czasie pomiędzy uzyskaniem doktoratu a habilitacją. Wielu spośród wspominanych powyżej badaczy

82 P. Mroczkowski, op. cit., s. 339.

83 C.K. Uniwersytet im. Cesarza Franciszka I we Lwowie. Program wykładów w pótroczu zimowym 1912/1913, Lwów 1912, s. 22; C.K. Uniwersytet im. Cesarza Franciszka I we Lwowie. Program wykładów w pótroczu letnim 1912/1913, Lwów 1913, s. 22.

${ }_{84}$ F. Butler uczył też w gimnazjach lwowskich. Sprawozdanie Dyrekcji c.k. Gimnazjum VIII we Lwowie za rok 1913, Lwów 1913, s. 39.

85 C.K. Uniwersytet im. Cesarza Franciszka I we Lwowie. Program wykładów w pótroczu zimowym 1912/1913, s. 22.

86 C.K. Uniwersytet im. Cesarza Franciszka I we Lwowie. Program wykladów w pótroczu letnim 1912/1913, s. 22.

87 C.K. Uniwersytet im. Cesarza Franciszka I we Lwowie. Program wykladów w pótroczu zimowym 1913/1914, Lwów 1913, s. 23; C.K. Uniwersytet im. Cesarza Franciszka I we Lwowie. Program wykładów w pótroczu letnim 1913/1914, Lwów 1914, s. 23.

88 T. Pudłocki, Władysław Tarnawski; dzieciństwo i młodość, „Rocznik Przemyski” 2001, t. 37, z. 1: Literatura i Język, s. 77-88; idem, Władysław Tarnawski. Cz. II. Przemyśl, lata przetomu, „Rocznik Przemyski” 2002, t. 38, z. 1: Literatura i Język, s. 67-78; idem, Władystaw Tarnawski. Cz. III. Przemyślanin $w$ drodze do katedry uniwersyteckiej, ,Rocznik Przemyski” 2004, t. 40, z. 3: Literatura i Język, s. 71-92. 
(nie tylko z pierwszego pokolenia profesorów filologii drugiej połowy XIX w.) miało doświadczenia w praktyce uczenia w szkole średniej i przez całą dalszą karierę nie tylko żywo interesowało się oświatą, ale także uczestniczyło w wielu działaniach na jej rzecz. Ważne były pożytki dla całego środowiska, więc wspólnie występowano w wielu kwestiach. Szczególnie było to widoczne w środowisku filologów klasycznych. Polityka wspierania przez państwo, poprzez finansowanie wyjazdów badawczych - zarówno studentów, jak i nauczycieli oraz badaczy (zwłaszcza z filologii klasycznej i germanistyki), miała bardzo korzystny wpływ na całe środowisko ${ }^{89}$. Świadome i samodzielne budowanie katedr romanistyki i anglistyki wskazywało z kolei na dążenia do poszerzania zakresu badań, realizowania własnych ambicji i budowania prestiżu poszczególnych uczelni. W wypadku katedr z filologii klasycznej po okresie posad dla Wielkopolan, wychowanków uniwersytetów berlińskich, przyszła kolej na rodzimych uczonych, którzy jako drugie pokolenie kształtowali tę dyscyplinę. Katedry germanistyczne powierzano do końca okresu autonomicznego uczonym z niemieckiego kręgu językowego. Katedry romanistyki i anglistyki objęli natomiast wychowankowie uniwersytetów galicyjskich, legitymujący się studiami zagranicznymi. Rozwój katedr z filologii klasycznych, podobnie jak germanistycznych, przebiegał równolegle na obu uczelniach. Niewielkie przesunięcie nastąpiło zaś w kreowaniu katedr romanistycznej i anglistycznej, które powstały wcześniej w Krakowie. Poza środowiskiem filologów klasycznych nie zbudowano dużych programów badawczych. Uczeni realizowali własne, zresztą bardzo szerokie zainteresowania, a ponieważ mieli świetną podbudowę ogólnohumanistyczną oraz znali od kilku do kilkudziesięciu języków obcych, pojawiło się wiele studiów szczegółowych, prac komparatystycznych, a następnie syntez oraz upowszechniających aktualny stan badań podręczników i prac słownikowych. Widoczna była też postępująca specjalizacja $\mathrm{w}$ badaniach, przejawiająca się w tworzeniu kilku katedr ze sfery poszczególnych filologii i zatrudnianiu docentów prywatnych, co pozwoliło na dalszy rozwój katedr filologicznych już w okresie II Rzeczypospolitej.

\section{BIBLIOGRAFIA}

\section{Źródła}

Archiwum Uniwersytetu Jagiellońskiego

WF II 121. Teczki akt habilitacyjnych: Roman Dyboski, Maksymilian Kawczyński, Kazimierz Morawski, Leon Sternbach.

WF II 161. Katedra i seminarium filologii angielskiej.

C.K. Uniwersytet im. Cesarza Franciszka I we Lwowie. Program wykładów w pótroczu ... [za lata 1910-1914, Lwów 1910-1914].

89 Zob. J. Dybiec, Finansowanie nauki i oświaty w Galicji 1860-1918, Kraków 1979. 
C.K. Uniwersytet im. Cesarza Franciszka I we Lwowie. Skład Uniwersytetu w roku akademickim... [1913/1914-1914/1915, Lwów 1913-1914].

Pamiętnik zjazdu historyczno-literackiego imienia Jana Kochanowskiego. Archiwum do dziejów literatury i oświaty w Polsce, t. V, Kraków 1886.

Skład Uniwersytetu Jagiellońskiego w Krakowie oraz wykaz przedmiotów naukowych wyktadać się mających w pótroczu letnim roku szkolnego 1851/1852, Kraków 1852.

Sprawozdanie Dyrekcji c.k. Gimnazjum VIII we Lwowie za rok 1913, Lwów 1913.

\section{Literatura}

Amsterdamski S., Tendencje rozwoju nauki w II połowie XIX wieku [w:] Historia nauki polskiej, t. IV: 1863-1918, cz. III, red. tomu Z. Skubała-Tokarska, Wrocław 1987, s. 7-39.

Baader G., Wilhelm Hartel [w:] Neue Deutsche Biographie (NDB), Bd. 7, Berlin 1966, s. 707-709.

Barycz H., U narodzin uniwersyteckiego studium filologii romańskiej w Polsce, „Przegląd Historyczno-Oświatowy" 1961, z. 1, s. 3-16.

Bieńkowski W., Emil Petzold, http://www.ipsb.nina.gov.pl/a/biografia/emil-petzold [dostęp: 12.08.2017].

Biernacki A., Edward Franciszek Porębowicz (1862-1937) [w:] Polski Stownik Biograficz$n y$, t. 27, 1982-1983, s. 648-652.

Ceran W., Historia i bibliografia rozumowana bizantynologii polskiej (1800-1998), t. 1, Łódź 2001.

Czerny Z., Filologia romańska w Uniwersytecie Jagiellońskim [w:] Wydział Filologiczny Uniwersytetu Jagiellońskiego. Historia katedr, red. W. Taszycki, A. Zaręba, Kraków 1964.

Dill U., Eduard Wölfflin [w:] Historisches Lexikon der Schweiz, http://www.hls-dhs-dss.ch/ textes/d/D43464.php [dostęp: 12.09.2017].

Dobijanka-Witczakowa O., František Tomáš Bratránek [w:] Złota Księga Wydziału Filologicznego, red. J. Michalik, W. Walecki, Kraków 2000, s. 49-57.

Dobijanka-Witczakowa O., Historia Katedry Germanistyki w Uniwersytecie Jagiellońskim [w:] Wydział Filologiczny Uniwersytetu Jagiellońskiego. Historia katedr, red. W. Taszycki, A. Zaręba, Kraków 1964, s. 349-366.

Dutkowa R., Adolf Mułkowski (1812-1867) [w:] Polski Stownik Biograficzny, t. 22, 1977, s. $259-260$.

Dybiec J., Finansowanie nauki i oświaty w Galicji 1860-1918, Kraków 1979.

Dybiec J., Uniwersytet Lwowski pod zaborem austriackim [w:] Universitati Leopoliensi. Trecentesimum quinquagesimum anniversarium suae fundationis celebranti in memoriam, red. W. Lehman, Kraków 2011, s. 66-76.

Finkel L., Starzyński S., Historia Uniwersytetu Lwowskiego, t. 1, Lwów 1894.

Glixelli S., Ś.p. Edward Porębowicz, „Pamiętnik Literacki” R. 34, 1937, nr 1-4, s. 374-377.

Gruchała J.S., Philologia Perennis. Tradycje badań filologicznych w Akademii Krakowskiej do początków XIX wieku [w:] Złota Księga Wydziału Filologicznego, red. J. Michalik, W. Walecki, Kraków 2000, s. 9-34.

Gubrynowicz B., Antoni Małecki (1821-1913), Lwów 1920. 
Hammer S., Kazimierz Morawski jako filolog i humanista (1852-1925), „Eos” R. 28, 1925, s. 229-243.

Haeberlin C., Gustav Linker [w:] Allgemeine Deutsche Biographie (ADB), Bd. 52, Leipzig 1906, s. 1-2.

Hornung M., Josef Schatz [w:] Österreichisches Biographisches Lexikon 1815-1950 (ÖBL), Bd. 10, Wien 1994, s. 45.

Jordan S., August Sauer [w:] Neue Deutsche Biographie (NDB), Bd. 22, Berlin 2005, s. 451.

Kalkhoff A.M., Romanische Philologie im 19. und frühen 20 Jahrhundert. Institutionengeschichtliche Perspektiven, Tübingen 2010.

Kraus K., Kazimierz Morawski (1852-1925) [w:] Złota Księga Wydziału Filologicznego, red. J. Michalik, W. Walecki, Kraków 2000, s. 117-125.

Królczyk K., Ludwik Ćwikliński (1853-1942), „Nowy Filomata” R. 14, 2010, z. 2, s. 83-94.

Królczyk K., Ludwik Ćwikliński (1853-1942) - lwowski uczony, działacz społeczny i polityk drugiej połowy XIX wieku [w:] Історична пам>ять україниів і поляків у період формування начіональної свідомості в XIX - першій половині XX століття, red. L. Zaszkilniak, J. Pisulińska, P. Sierżęga, Lviv 2011, s. 96-114.

Królczyk K., Polscy badacze starożytności na Uniwersytecie Lwowskim (1873-1939) szkic do portretu [w:] Haec mihi in animis vestris templa. Studia Classica in Memory of Professor Lesław Morawiecki, red. P. Berdowski, B. Balahaczek, Rzeszów 2007, s. $23-46$.

Kumaniecki K., Ludwik Ćwikliński, „Pamiętnik Literacki” R. 36, 1946, s. 96-103.

Lipiński K., Wilhelm Creizenach (1851-1919) [w:] Złota Księga Wydziału Filologicznego, red. J. Michalik, W. Walecki, Kraków 2000, s. 107-115.

Loužil J., F.T. Bratraneks Leben und Philosophie, „Bohemia. Jahrbuch des Collegium Carolinum", Bd. 13, München-Wien 1972.

Loužil J., Franz Thomas Bratranek (1815-1884) [w:] Wegbereiter der deutsch-slawischen Wechselseitigkeit, ed. E. Winter, G. Jarosch, Berlin 1983.

Loužil J., Franz Thomas Bratraneks Beitrag zum Aldalbert - Stifter - Verständnis, „Philologica Pragensia" 1990, vol. 33, č. 1, s. 20-28.

Madyda W., Z dziejów filologii klasycznej w Uniwersytecie Jagiellońskim [w:] Wydział Filologiczny Uniwersytetu Jagiellońskiego. Historia katedr, red. W. Taszycki, A. Zaręba, Kraków 1964, s. 1-94.

Michalewska K., Habilitacje w Uniwersytecie Jagiellońskim 1848-1918, Kraków 1963.

Michat Jezienicki, „Przegląd Klasyczny” R. 2, 1936, z. 2, s. 151-155.

Mroczkowski P., Historia Katedry Filologii Angielskiej w Uniwersytecie Jagiellońskim [w:] Wydzial Filologiczny Uniwersytetu Jagiellońskiego. Historia katedr, red. W. Taszycki, A. Zaręba, Kraków 1964.

Ogrodziński W., Wielkopolanie na katedrze filologii klasycznej w Krakowie w XIX wieku, Poznań 1936.

Ölberg H.M., Bernhard Jülg [w:] Neue Deutsche Biographie (NDB), Bd. 10, Berlin 1974, s. 642.

Perkowska U., Corpus Academicorum Facultatis Philosophiae Universitatis Iagellonicae 1850-1945, Kraków 2007.

Pichl R., August Sauer [w:] Österreichisches Biographisches Lexikon 1815-1950 (ÖBL), Bd. 9, Wien 1988, s. 438.

Pilch S., Ludwik Ćwikliński. 80-lecie urodzin i diamentowe gody z nauka, „,Kwartalnik Klasyczny” R. 7, 1933, z. 4, s. XV-XLIV. 
Plezia M., Filologia klasyczna [w:] Historia nauki polskiej, t. IV: 1863-1918, cz. III, red. tomu Z. Skubała-Tokarska, Wrocław 1987.

Pótwiekowe dzieje Kótka Filologicznego U.U.J. 1879-1929, Kraków 1930.

Pudłocki T., Władysław Tarnawski; dzieciństwo i młodość, „Rocznik Przemyski” 2001, t. 37, z. 1: Literatura i Język, s. 77-88.

Pudłocki T., Władysław Tarnawski. Cz. II. Przemyśl, lata przełomu, „Rocznik Przemyski” 2002, t. 38, z. 1: Literatura i Język, s. 67-78.

Pudłocki T., Władysław Tarnawski. Cz. III. Przemyślanin w drodze do katedry uniwersyteckiej, ,Rocznik Przemyski” 2004, t. 40, z. 3: Literatura i Język, s. 71-92.

Sinko T., Ludwik Ćwikliński, „Kwartalnik Historyczny” R. 53, 1939-1945, s. 463-468.

Smereka J., Filologia klasyczna w Uniwersytecie Lwowskim do czasów Zygmunta Węclewskiego i Ludwika Ćwiklińskiego, Lwów 1937.

Smereka J., Pierwszy filolog-Polak w Uniwersytecie Jana Kazimierza - Zygmunt Węclewski. W 50-ta rocznice śmierci, „Eos” R. 39, 1938, z. 2, s. 217-238.

Stinia M., Jagiellonen-Universität in den Zeiten des Ministers Leo Thun (1849-1860) [w:] Die Thun-Hohenstein'schen Universitätsreformen 1849-1860. Konzeption - Umsetzung - Nachwirkungen, Hrsg. B. Mazohl, Ch. Aichner, Wien 2017, s. 198-220.

Stinia M., Uniwersytet Lwowski [w:] Szkolnictwo i oświata w Galicji 1772-1918, red. J. Dybiec, J. Krawczyk, A. Meissner, K. Szmyd, Galicja i Jej Dziedzictwo, t. 22, Rzeszów 2015, s. 206-222.

Śp. Dr. Michat Jezienicki 1859-1935, „Eos” R. 36, 1935, s. 477-480.

Wiesinger P., Joseph Schatz (1871-1950) Sprachwissenschaftler, Dialektologe und Philologe an der Universitäten Innsbruck und Lemberg, „Вісник Львівського Університету”, Серія історична, Випуск 49, Львів 2013.

Wilhelm Hartel [w:] Österreichisches Biographisches Lexikon 1815-1950 (ÖBL), Bd. 2, Wien 1959, s. 192.

Wiszniewski M., Historia literatury polskiej, t. 1, Kraków 1840. 